\title{
Health impact assessment - theory into practice
}

After several years of discussion, ${ }^{12}$ we are finally seeing the health impact assessment of policies, programmes, and projects in developed countries becoming a practical reality. Health impact assessment, which has been defined as "the estimation of the effects of a specified action on the health of a defined population", ${ }^{3}$ has developed out of the now universal acknowledgement of the health effects of public policy, ${ }^{4}$ coupled with a quarter century's experience of the assessment of environmental impact. ${ }^{5}$

In the United Kingdom, considerable encouragement to the development of health impact assessment has come from the enthusiasm of central government for the concept. Although research and development was under way ${ }^{6}$ before the election of the current administration in May 1997, the Labour government's commitment to addressing the health impacts of its public policies cannot be doubted. Three recent consultative documents on public health strategy have referred to the necessity for health impact assessment of both national and local policies and projects. ${ }^{8-10}$ The Scottish Office Department of Health has circulated a discussion paper on the development of health impact assessment in Scotland ${ }^{11}$ to directors of public health, and the English health department is supporting a special interest group, funding research and development into health impact assessment and co-sponsoring a national conference in November 1998.

Although the European Commission has been slow to follow up its statement that Article 129 of the European Union Treaty "requires the Commission to check that proposals for policies, and implementing measures and instruments, do not have an adverse impact on health, or create conditions which undermine the promotion of health", ${ }^{12}$ it has now begun to commission research directed toward this objective. ${ }^{13}$

A number of developed countries are also undertaking such work. The greatest experience has been gained in the Canadian province of British Columbia, where in 1993 the provincial government agreed that health impact assessment would in future be part of the approval process for all new government policy, programmes, and legislation. This was followed by the development of a toolkit for use by policy analysts in preparing the health impact section of cabinet submissions, and a set of guidelines for use in programme planning and development. ${ }^{7}$ These are currently under review (Lewis C, personal communication).

In 1996, Sweden's National Institute of Public Health published a health impact assessment of the European Union's Common Agricultural Policy. ${ }^{14}$ In the United Kingdom, Liverpool University's Public Health Observatory has been developing systematic methods for health impact assessment, in the course of a programme of case studies evaluating urban policies and projects. The Liverpool approach ${ }^{15}$ builds on a framework involving:

- the application of a set of screening criteria for the selection of policies or projects for assessment;

- profiling of the areas and communities affected;

- applying a predefined model of health to predict potential impacts;

- evaluating the importance, scale, and likelihood of potential impacts;

- option appraisal and recommendations for action.

Examples of screening criteria include the size and distribution of project costs and of affected populations; the likely frequency, severity, and probability of potential health impacts; and the strategic relevance and timeliness of the proposed assessment. Depending on the nature of the project or policy, profiling may define affected communities by their location, characteristics (for example, children, people in poverty), common interests (for example, users of leisure centres) or behaviours (for example, public transport users). Environmental conditions and latent periods may mean that such communities are distant in space or time from the intervention under study. Methods for obtaining data on potential impacts are both qualitative (policy analyses, interviews with key informants) and quantitative (estimations of morbidity, mortality or of risk factors, such as noise or accidents).

The major focus of development work has been on prospective methods for health impact assessment. Ideally, assessment should take place early enough in the development of a policy or project to permit constructive modifications to be carried out before its implementation, but late enough for a clear idea to have been formed as to the nature and content of the proposal. In the words of the song, the aim is as far as possible to accentuate the positive and eliminate the negative. It is, however, important to recognise that the knowledge base for prospective studies essentially derives from existing retrospective assessments of the health impacts of public policies, and of environmental accidents and disasters. While some attempts have been made to collate this literature, ${ }^{16}{ }^{17}$ it is clear that more systematic work will be required. ${ }^{5}$

The opportunity costs of undertaking health impact assessment imply a need for rapid appraisal methods to complement the more in depth assessments appropriate to the implementation of major policies or environmental developments. It has been suggested that the relatively simple screening tools used for the selection of case studies could themselves serve as a basis for rapid policy or project appraisa $1^{18}$ - though this suggestion remains to be critically evaluated.

The model of health used by practitioners is crucial to both the health impact assessment process and its outcomes. Work in less developed countries has tended to use a medical model, focusing on possible disease outcomes of project proposals. ${ }^{19}$ In developed countries, a model that incorporates a more holistic concept of health and a broad range of social determinants is more appropriate. In Liverpool we are using a socioenvironmental model $^{15}$ derived from the work of Lalonde ${ }^{20}$ and Labonté. ${ }^{21}$ Clearly, such concepts of health in turn result in the identification of broader ranges of potential impacts of projects or policies.

Like health itself, health impact assessment is not valueneutral; the values used and the processes and outcomes they generate should be explicitly stated. Equity is a key value in health impact assessment, because public policy impacts disproportionately on the already disadvantaged. From the adoption of an equity focused approach follow the need for participatory methods and for openness of all stages of the evaluation process to public scrutiny.

Good methodology results in methods appropriate to what is being studied; it is not therefore possible to prescribe one ideal method for appraising the broad range of health relevant public policy. What can be said is that multi-method approaches are likely to be required, and that these will usually be both qualitative and quantitative, multi- and inter-disciplinary.

Health impact assessment is at an early stage in its development. If it is indeed to be the case that in 10 years 
time it will be as important as doctors now regard clinical trials $^{22}$ - in other words, a key influence on evidence-based health policy ${ }^{23}$-an international programme of research and development needs to get under way at the earliest opportunity.

Liverpool Public Health Observatory,

ALEX SCOTT-SAMUEL

Department of Public Health, University of Liverpool,

Whelan Building, Quadrangle, Liverpool L69 3GB

Funding: the author's own work referred to in this editorial is funded by Liverpool, St Helens and Knowsley, Sefton and Wirral Health Authorities.

Conflicts of interest: none.

1 Scott-Samuel A. Health impact assessment. BMf 1996;313:183-4.

2 Ratner PA, Green LW, Frankish CJ, et al. Setting the stage for health impact Ratner PA, Green LW, Frankish CJ, et al. Setting the
assessment. F Public Health Policy 1997;18:67-79.

3 Scott-Samuel A. Assessing how public policy impacts on health. Healthlines 1997; no 47:15-17 (November 1997)

4 Draper P, ed. Health through public policy. London: Green Print, 1991.

5 Birley M, Boland A, Davies L, et al. Health and environmental impact assessment - an integrated approach. London: Earthscan, 1998.

6 Department of Health. Policy appraisal and health. London: Department of Health, 1995.

7 Winters L. Health impact assessment - a literature review. Observatory report series no 36. Liverpool: Liverpool Public Health Observatory, 1997.

8 Secretary of State for Scotland. Working together for a healthier Scotland. Cm 3584. Edinburgh: The Stationery Office, 1998

9 Secretary of State for Health. Our healthier nation: a contract for health $\mathrm{Cm}$ 3852. London: The Stationery Office, 1998.
10 Secretary of State for Wales. Better health - better Wales. Cm 3922. London: The Stationery Office, 1998.

11 Douglas M. Health impact assessment: a way forward for Scotland. Edinburgh: The Scottish Office Department of Health, 1998

12 Commission of the European Communities. Report from the commission to the council, the European parliament and the economic and social committee on the integration of health protection in community policies (COM (95)196 final of 29 May 1995). Brussels: CEC, 1995

13 Commission of the European Communities. Third report from the commission to the council, the European parliament, the economic and social committee and the committee of the regions on the integration of health protection requirements in com-
munity policies (COM (1998) 34 final of 27.01.98). Brussels: CEC, 1998.

14 Dahlgren G, Nordgren P, Whitehead M, eds. Health impact assessment of the EU Common Agricultural Policy. Stockholm: Swedish National Institute of Public Health, 1996.

15 Winters L, Scott-Samuel A. Health impact assessment of the community safety projects - Huyton SRB area. Observatory report series no 38. Liverpool: Liverpool Public Health Observatory, 1997.

16 Canadian Public Health Association. Health impacts of social and economic conditions: implications for public policy. Ottawa: CPHA, 1997.

17 Koivusalo M, Ollila E, Santalahti P. Intersectoral action for health in Finland. Themes 7/1997. Helsinki: Health Services Research Unit, National Research and Development Centre for Welfare and Health, 1997.

18 Milner S, Marples G. Policy appraisal and health project. Phase 1 - a literature review. Newcastle: University of Northumbria at Newcastle, 1997.

19 Birley MH. The health impact assessment of development projects. London: HMSO, 1995.

20 Lalonde M. A new perspective on the health of Canadians. Ottawa: Ministry of Supply and Services, 1974

21 Labonté R. Health promotion and empowerment: practice frameworks. Toronto: Centre for Health Promotion, University of Toronto and ParticipAction, 1993.

22 Beecham L. All policies should be assessed for effect on health. BMf 1998; 316:1558 (http://www.bmj.com/cgi/content/full/316/7144/1558/c).

23 Ham C, Hunter DJ, Robinson R. Evidence based policymaking. BMF 1995; 310:71-2. 